\title{
Effect of Total Mixed Ration Feeding with Roughage: Concentrate Ratio of 60:40 on Performance and Residual Feed Intake of Crossbred Cows
}

\author{
Jyoti Sumer Kajla ${ }^{1}$, R.S. Grewal ${ }^{1 *}$, Jasmine Kaur ${ }^{1}$, J.S. Lamba ${ }^{1}$, \\ Simarjit Kaur $^{2}$ and PuneetMalhotra ${ }^{2}$ \\ ${ }^{1}$ Department of Animal Nutrition, GADVASU, Ludhiana, India \\ ${ }^{2}$ Directorate of Livestock Farms, GADVASU, Ludhiana, India \\ *Corresponding author
}

\begin{abstract}
A B S T R A C T
Keywords

Total mixed ration, RFI, Roughage: concentrate ratio

Article Info

Accepted:

20 March 2019

Available Online:

10 April 2019

High yielding crossbred cows are fed high amount of concentrate which poses metabolic disorders. TMR feeding is suitable for high concentrate feeding. RFI is a measure of efficiency which has not been explored in crossbred cows. Therefore present study was undertaken to study the effect of TMR feeding of performance and RFI in crossbred cows. Twelve cows were divided in to two groups of six animals each and fed ration with 60:40 roughage: concentrate ratio. The animals were fed individually and daily feed intake and refusal were recorded. The DM intake was calculated. The data showed that the DM intake of was similar in both the groups. On DMI basis, RFI, when calculated on DMI basis, was significantly $(\mathrm{P}<0.05)$ lower in TMR as compared to NON-TMR. The digestibility of DM, $\mathrm{CP}, \mathrm{ADF}, \mathrm{NDF}$ and TDN was significantly $(\mathrm{P}<0.05)$ higher in TMR as compared to NON-TMR. The TMR feeding had significantly positive $(\mathrm{P}<0.05)$ effect on milk production, and milk energy yield. The RFI had negative correlation with intake and digestibility parameter of ration.
\end{abstract}

\section{Introduction}

The feeding system based on TMR is ideal for the high yielding dairy animals because when fed high concentrate ration these animals are prone to metabolic disorder like acidosis, lameness etc. These problems could be minimized or totally eliminated when feeding is done as TMR. Residual feed intake can be calculated by measuring an animal's actual feed intake and estimating what the animal should be eating based on gain and production. Estimated feed intake is then subtracted from actual feed intake. Genetic selection to reduce RFI can result in progeny that eat less without sacrificing performance (Herd et al., 1997 and Richardson et al., 1998). There are not many studies on TMR feeding and RFI in crossbred cows. Therefore, present experiment is planned to study the effect of TMR feeding on performance and RFI of lactating crossbred cows.

\section{Materials and Methods}

The concentrate was prepared for formulating TMR as per table 1. The TMR consisted of 
concentrate- $7 \mathrm{~kg}$, wheat straw- $2 \mathrm{~kg}$ and nonlegume silage- $36 \mathrm{~kg}$ (adjusted weekly on DM basis).

The experiment was conducted at Guru Angad Dev Veterinary and Animal Sciences University, Ludhiana. Twelve cows were divided in to two groups of six animals each and fed ration with 60: 40 roughage: concentrate ratio. The animals were fed individually and daily feed intake and refusal was recorded. The DM, OM, CP, NDF, ADF, $\mathrm{EE}$ and energy intakes were calculated. The cows were stall fed throughout the experimental period. Fresh and clean water was provided thrice a day i.e. morning, afternoon and evening throughout the experimentation. Proper hygienic conditions and healthy surrounding were maintained in the shed throughout the experimental feeding period. During the research period, health status of cows was monitored regularly. This feeding experiment was of 45 days duration

The sample of feed and refusal were taken twice weekly for analysis for proximate principles (AOAC 2000) and cell wall fractions (VanSoest, 1963). The body weight of animals was recorded fortnightly. The milk was measured daily and milk composition was estimated at weekly intervals. Residual feed intake estimation was measured by the method given by (Koch et al., 1963). The estimated intakes was calculated from regression of actual intake energy yielded in milk MJ/d (LE) and live body weight changes (expressed per unit metabolic body size defined as LW) and the fitted values taken as estimated intakes (Veerkamp et al., 1995). Actual intakes were regressed on milk yield, milk energy yield and the two way interaction between milk yield (MY) and live weight change (LWC). The actual ME intake and predicted ME intake were also estimated. The correlations of RFI with various animal and dietary parameters were calculated.

\section{Experimental feeds offered to crossbred cows in different groups}

\begin{tabular}{|l|l|}
\hline $\begin{array}{l}\text { Experimental } \\
\text { group }\end{array}$ & Experimental feed \\
\hline NON-TMR & $\begin{array}{l}\text { Silage + Wheat straw + concentrate } \\
\text { without mixing }\end{array}$ \\
\hline TMR & $\begin{array}{l}\text { Silage + Wheat straw + concentrate } \\
\text { with proper hand mixing }\end{array}$ \\
\hline
\end{tabular}

A digestion trial was conducted for 7 days on all experimental cows after 50 days of feeding trial. Collection of feaces was done on 24 hourly basis. Simultaneously daily feed offered and residue left was recorded. The representative samples of feed offered, residue left and feaces voided were collected and analyzed for proximate principles by the methods of (AOAC 2000) in order to determine the digestibility of different nutrients viz. dry matter, crude protein, ether extract, total ash, ADF and NDF.

\section{Results and Discussion}

The data showed that the DM intake was similar in both the groups. On DMI basis, RFI, when calculated on DMI basis, was significantly $(\mathrm{P}<0.05)$ lower in $\mathrm{TMR}$ as compared to NON-TMR (Table 2).

Data revealed that the digestibility of DM, $\mathrm{CP}, \mathrm{ADF}, \mathrm{NDF}$ and TDN \% was significantly ( $\mathrm{P}<0.05$ ) higher in TMR as compared to NON-TMR, however, mode of feeding had no significant effect on $\mathrm{OM}, \mathrm{EE}$ and $\mathrm{CHO}$ digestibility (Table 2). Raja Kishore et al (2013) reported similar results. They found that the DM intake $(\mathrm{kg} / \mathrm{d})$ was similar in TMR and non-TMR groups in buffalo bulls. They found that the digestibility (\%) of $\mathrm{CP}, \mathrm{EE}, \mathrm{CF}$, $\mathrm{NDF}, \mathrm{ADF}$, hemi-cellulose and cellulose were higher $(\mathrm{P}<0.01)$ in animals fed complete rations than those fed conventional ration.

The data pertaining to effect of mode of feeding as TMR or NON-TMR on ilk 
production and composition in low concentrate group is given in table 3 . The TMR feeding had significantly positive ( $P$ $<0.05$ ) effect on milk production, and milk energy yield. However, the milk protein $\%$ was significantly $(\mathrm{P}<0.05)$ higher in NONTMR as compared to TMR.

This might be due to some sorting of feed ingredients taking place in NON-TMR group. TMR and NON-TMR had no significant effect on milk/kg MBW, fat \%, fat yield, protein yield and FCM. Gupta et al (2014) found overall average increase in milk production by $18.22 \%$ in cows fed TMR. They concluded that feeding of TMR is beneficial for proportionate intake of all feed ingredients, overall feed intake and better digestibility of nutrients resulting into higher milk production. Schraufnagel (2007) also reported that TMR has a positive effect on milk yield and profits. Similar results are reported by Bargo et al., (2002).

The RFI had negative correlation with intake and digestibility parameter of ration (Table 4). Richardson and Herd (2004) also found negative correlation between RFI and digestibility.

They performed a divergent selection experiment for residual feed intake in Angus beef cattle progeny to help determine mechanisms underlying the variation in RFI. They found a correlation of -0.44 between RFI and digestibility.

Table.1 Composition of TMR fed to animals

\begin{tabular}{|l|l|}
\hline Parameter & Composition, \% DM \\
\hline OM & 91.47 \\
\hline CP & 14.34 \\
\hline NDF & 42.61 \\
\hline ADF & 25.86 \\
\hline EE & 3.06 \\
\hline Ash & 8.53 \\
\hline
\end{tabular}

Table.2 Effect of TMR or NON-TMR ration on intake, nutrient digestibility and RFI

\begin{tabular}{|l|l|l|l|l|}
\hline Parameter & TMR & NON TMR & SE & p value \\
\hline DMI, kg/day & 17.50 & 17.45 & 0.06 & 0.33 \\
\hline Digestibility coefficient \% & \multicolumn{4}{|l|}{} \\
\hline DM & 65.76 & 61.88 & 1.30 & 0.001 \\
\hline OM & 70.26 & 71.25 & 0.77 & 0.37 \\
\hline CP & 69.64 & 66.72 & 1.23 & 0.05 \\
\hline EE & 80.42 & 78.35 & 1.04 & 0.06 \\
\hline NDF & 60.24 & 52.80 & 2.40 & 0.001 \\
\hline ADF & 65.86 & 63.67 & 0.86 & 0.03 \\
\hline CHO & 63.04 & 61.33 & 0.99 & 0.12 \\
\hline TDN \% & 64.59 & 62.06 & 1.07 & 0.04 \\
\hline RFI, kg/day(DM) & -2.69 & 1.07 & 0.01 & 0.03 \\
\hline
\end{tabular}


Table.3 Effect of TMR or NON-TMR ration on Milk production and composition

\begin{tabular}{|l|l|l|l|l|}
\hline Parameter & TMR & NON-TMR & SE & p valve \\
\hline Milk yield kg/day & 14.81 & 12.02 & 0.77 & 0.05 \\
\hline Milk/kg MBW & 0.53 & 0.50 & 1.45 & 0.20 \\
\hline Milk energy yield, MJ/day & 45.96 & 40.92 & 1.91 & 0.02 \\
\hline Fat \% & 3.69 & 3.77 & 0.18 & 0.38 \\
\hline Fat yield kg/day & 0.55 & 0.45 & 0.03 & 0.09 \\
\hline Protein \% & 3.00 & 3.11 & 0.08 & 0.04 \\
\hline Protein yield kg/day & 0.44 & 0.37 & 0.04 & 0.21 \\
\hline FCM kg/day & 14.86 & 13.16 & 1.25 & 0.10 \\
\hline RFI & -1.36 & 1.14 & 0.45 & 0.001 \\
\hline
\end{tabular}

Table.4 Correlation of RFI with different intake and digestibility parameter

\begin{tabular}{|l|l|}
\hline Parameter & Correlation \\
\hline DMI kg/day & -0.27 \\
\hline OMD & -0.78 \\
\hline DMD & -0.84 \\
\hline AFMD & -0.68 \\
\hline NDFD & -0.61 \\
\hline EED & -0.56 \\
\hline ME INTAKE $\mathbf{M J / d a y}$ & -0.85 \\
\hline NE INTAKE $\mathbf{M J / d a y}$ & -0.85 \\
\hline
\end{tabular}

In conclusion, TMR and NON-TMR had nonsignificantly effect on intake parameter. Nutrient digestibility is significantly $(\mathrm{p}<0.05)$ higher for DM, CP, EE, ADF, NDF and TDN in TMR compared to NON-TMR rations. The TMR had significantly $(\mathrm{p}<0.05)$ positive effect on milk yield, milk energy yield and FCM yield. TMR had significantly $(\mathrm{p}<0.05)$ lower RFI as compared to NON-TMR indicating better efficiency in TMR groups. The correlation of RFI with DMI, OMD, DMD, AFMD, EED, NDFD, MEI, NEI was negative.

\section{References}

AOAC. 2000. Official Method of Analysis $\left(17^{\text {th }}\right.$ ed.) Association of Official Analytical Chemists, Inc., Maryland, USA.
Bargo, F., Muller L D., Delahoy J E and Cassidy T W. 2002. Performance of high producing dairy cows with three different feeding systems combining pasture and total mixed rations. Journal of Dairy Science 85(11): 2948-63.

Herd, R M., Archer J A, Arthur P F, Richardson E C, Wright J H, Dibley K C P and Burton D A. 1997. Performance of progeny of high vs. low net feed conversion efficiency cattle. Association for the Advancement of Animal Breeding and Genetics12: 742-45.

Koch, R M., Swiger, L A., Chambers D and Gregory K E. 1963. Efficiency of feed use in beef cattle. Journal of Animal Sciences 22: 486-94.

Raja Kishore, K., Srinivas Kumar, D., and 
Ramana J V. 2013. Effect of feeding crop residue based complete rations on nutrient utilization in buffalo bulls. International Journal of Agriculture Science and Veterinary Medicine

Richardson, E.C., and Herd, R.M., 2004. Biological basis of variation in residual feed intake in beef cattle. 1 . Review of potential mechanisms. Australian Journal of Experimental Agriculture 44: 423-30.

Schraufnagel, S., 2007. Technology Systems

and Business Performance on
Wisconsin Dairy Farms. University of Wisconsin-River Falls.

Van Soest, P.J., 1963. Ruminant fat metabolism with particular reference to factors affecting low milk fat and feed efficiency: Review Article. Journal of Dairy Science 46: 204-16.

Veerkamp, R., and Emmans G C., 1995. Sources of genetic variation and efficiency of dairy cows. Livestock Production Science 44: 87-97.

\section{How to cite this article:}

Jyoti Sumer Kajla, R.S. Grewal, Jasmine Kaur, J.S. Lamba, Simarjit Kaur and PuneetMalhotra. 2019. Effect of Total Mixed Ration Feeding with Roughage: Concentrate Ratio of 60:40 on Performance and Residual Feed Intake of Crossbred Cows. Int.J.Curr.Microbiol.App.Sci. 8(04): 2866-2870. doi: https://doi.org/10.20546/ijcmas.2019.804.334 